\title{
A COMPARISON OF SPERMATOZOA PRODUCTION AND SPERMATOZOA OUTPUT OF YORKSHIRE AND LACOMBE BOARS
}

\author{
E. E. SWIERSTRA \\ Research Station, Canada Department of Agriculture, Brandon, Manitoba, Canada
}

(Received 29th December 1967)

\begin{abstract}
Summary. A procedure is described for measuring daily spermatozoa production (DSP) from quantitative testicular histology. The mean DSP, as determined by this procedure, was $16.5 \times 10^{9}$ for ten Yorkshire boars (av. age 11.2 months) and $17.8 \times 10^{9}$ for ten Lacombe boars (av. age 11.3 months). The spermatozoa output was $88 \%$ of the DSP for the Yorkshire boars and $83 \%$ of the DSP for the Lacombe boars when semen samples were collected at 48-hr intervals. Spermatozoa output was significantly correlated $(+0.54)$ with spermatozoa production. The two breeds did not differ significantly with respect to DSP, but within breeds certain boars produced more spermatozoa than others $(P<0.05)$. The DSP per gram of testis was $25 \cdot 1 \times 10^{6}$ for Yorkshire boars and $24.3 \times 10^{6}$ for Lacombe boars $(P>0.05)$. The relative volume of the testes occupied by spermatids with round nuclei did not differ significantly between breeds, among boars within breeds nor between right and left testes. This suggests that for the boar, spermatozoa production is mainly a function of testis size. Results obtained by the procedure for measuring DSP were not significantly influenced by different staining techniques.
\end{abstract}

\section{INTRODUCTION}

Daily spermatozoa production (DSP) and daily spermatozoa output (DSO) have been measured for several species of animals. Daily spermatozoa production is the number of spermatozoa passing from the testis into the caput epididymidis daily. Spermatozoa output generally refers to the number of spermatozoa collected by means of an artificial vagina or by electro-ejaculation. There are many reports in the literature on spermatozoa output but results vary greatly among experiments. Differences in age of the animals, in semen collection techniques, in extra-gonadal spermatozoa reserves at the start of the semen collection period, in degree of sexual preparation before ejaculation and in ejaculation frequencies account for much of the variability of DSO (Hale \& Almquist, 1960).

Procedures reputed to measure DSP can be grouped into three categories; 
methods employing frequent semen collections, methods employing direct counts of spermatids in homogenized testes, and methods based on quantitative testicular histology. As discussed by Hale \& Almquist (1960) and Amann \& Almquist (1962) the first method does not measure DSP but rather DSO. Amann \& Almquist (1962) first suggested that DSP could be calculated from the number of spermatids present in suspensions of homogenized testes. The total number of spermatids counted was divided by the life-span of the counted spermatids in order to derive an estimate of DSP. Using this technique, the DSP for twenty-five mature dairy bulls was found to average $13.1 \times 10^{9}$ (Almquist \& Amann, 1961). Two approaches have been used to measure DSP from quantitative testicular histology. Amann \& Almquist (1962) counted the number of spermatids in a series of seminiferous tubules and used these data combined with information on testis composition and specific knowledge of the duration of spermatogenesis as the basis for calculating DSP. The DSP of twelve dairy bulls averaged $12.76 \times 10^{9}$. Kennelly \& Foote (1964) used the total volume of primary spermatocytes in the testes and the life-span of primary spermatocytes as the basis for calculating DSP of boars. Swierstra (1966) modified this method by using spermatids instead of primary spermatocytes and by correcting for shrinkage due to histological processing.

The objectives of this research were (1) to compare daily spermatozoa production of Yorkshire and Lacombe boars, (2) to compare their daily spermatozoa production with the actual number of spermatozoa obtained when semen samples were collected at $48-\mathrm{hr}$ intervals, (3) to relate testis characteristics to spermatozoa production and output, and (4) to evaluate certain aspects of the methodology for determining daily spermatozoa production.

\section{MATERIALS AND METHODS}

\section{Animals and semen collection procedure}

Spermatozoa production and output were studied in ten Yorkshire and ten Lacombe boars. The boars were housed in individual pens in a temperaturecontrolled barn (January to March). They had free access to water and were hand-fed twice a day. Semen samples were collected by means of a 'dummy' and an artificial vagina (Swierstra \& Rahnefeld, 1967). One semen sample was collected every $48 \mathrm{hr}$ for 8 weeks from each of the boars. Immediately after ejaculation, the percentage of motile spermatozoa, spermatozoa concentration, total volume and strained volume of each semen sample were determined. Spermatozoa concentration was determined by optical density (Young, Foote, Turkheimer \& Hafs, 1960). The total number of spermatozoa per ejaculate was calculated, taking into account spermatozoa losses in the collection equipment and gelatinous fraction of the ejaculate. Swierstra \& Rahnefeld (1967) calculated that these losses equalled $3.28 \%$ of the number of spermatozoa present in the collection bottle.

After the last ejaculation all boars were castrated and the weight of each testis, tunica albuginea and epididymis recorded. At castration, the Yorkshire boars were 11.2 months (10.5 to 11.7 months) and the Lacombe boars 11.3 months 
(10.3 to 11.7 months) old. The Yorkshires averaged $150 \mathrm{~kg}$ and the Lacombes $165 \mathrm{~kg}$ in body weight.

\section{Histological procedures}

The testes were cut mid-sagittally and pieces of tissue removed from three specified loci. Locus A was chosen near the caput epididymidis, locus B midway between the poles of the testis and locus $\mathrm{C}$ near the cauda epididymidis. Tissue samples were fixed in Allen's fixative (Gray, 1958) for 3 days. After fixation the samples were left overnight in $70 \%$ ethyl alcohol. The next morning they were dehydrated in a graded series of alcohols and cleared in xylene. Paraffin impregnation (Tissuemat, m.p. $55^{\circ} \mathrm{C}$ ) was carried out under vacuum $(50 \mathrm{~cm}$ of $\mathrm{Hg}$ ). Three changes of paraffin were used and the samples were left in each change for $30 \mathrm{~min}$. Histological sections were prepared from tissue representing each locus. Some of the histological slides from each locus were stained by the periodic acid-Schiff-haematoxylin (PAS-haem) technique and some by the Feulgen technique using fast green as a counterstain.

\section{Predicting daily spermatozoa production from quantitative histology}

The daily spermatozoa production of the testes (DSP) was determined by the method of Swierstra (1966) using the following formula:

$$
\text { DSP per testis }=\frac{\begin{array}{l}
\text { Corrected } \\
\text { testis volume }
\end{array} \times \begin{array}{l}
\text { Volume \% round spermatid } \\
\text { nuclei in the testis }
\end{array}}{\begin{array}{l}
\text { Av. volume per round } \\
\text { spermatid nucleus }
\end{array} \times \begin{array}{l}
\text { Life-span of round } \\
\text { spermatids in days }
\end{array}}
$$

The corrected testis volume was obtained by the following formula:

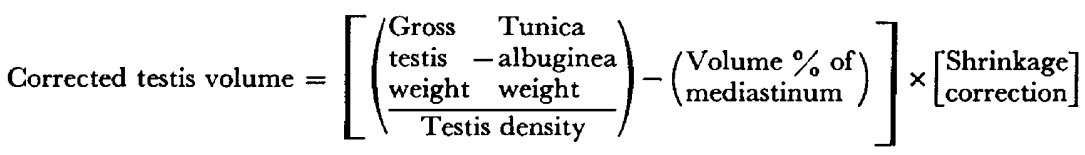

The volume $\%$ of round spermatid nuclei in the testes was determined by Chalkley's procedure (Chalkley, 1943). One Feulgen stained and one PAShaem stained section ( $4 \mu$ thick) were randomly selected from each location for analysis. For each section, two technicians observed 130 randomly chosen microscope fields and recorded the structures at the end of the five pointers in the ocular. This resulted in 7800 hits or recorded structures per testis. The structures were classed as (1) spermatids with round nuclei, (2) other testicular structures, and (3) artifacts. Before analysis of variance all percentages were transformed to arcsin (Snedecor, 1957).

The average volume per round spermatid nucleus was obtained by calculating a weighted mean diameter and substituting this value in the formula for a sphere. This weighted mean diameter was obtained from spermatid diameters in stages $4,5,6,7,8$ and 1 of the cycle of the seminiferous epithelium, and the duration of the respective stages (Swierstra, 1968). In each stage, twelve whole nuclei were measured in each of five boars. The nuclei were measured at right angles and the two measurements averaged. All measurements were 
made on Feulgen stained sections cut at $12 \mu$. The weighted mean diameter of a round spermatid nucleus was 5.07 $\mu$ and the mean volume $68.20 \mu^{3}$.

Studies with $\left[{ }^{3} \mathrm{H}\right]$ methylthymidine have shown that the life-span of boar spermatids with round nuclei is 6.34 days (Swierstra, 1968).

It was assumed that the volume of the mediastinum equalled $1 \%$ of the testis volume. This value was reported by Amann (1962a) for the volume of the mediastinum of bull testes.

\section{Shrinkage due to histological processing}

Shrinkage of testicular tissue due to histological processing was determined in a separate experiment involving an additional five Yorkshire and five Lacombe boars. These boars were of a similar age (10.6 to 11.6 months) to the boars used for studying spermatozoa production and output. Eight pieces of tissue were removed from each of the twenty testes. The tissue samples, similar in size to the pieces ultimately used for histological analyses averaged $0 \cdot 81 \pm 0 \cdot 01 \mathrm{~g}$. The eight tissue samples from each testis were randomly assigned to four groups and fixed in Allen's fixative (Gray, 1958). Groups I, II, III and IV were fixed for 3, 6, 6 and 9 days, respectively. Groups I, II and IV were dehydrated and embedded as outlined under Histological procedure. Group III tissue samples were processed as above except that they were left for $60 \mathrm{~min}$ in each of the three changes of Tissuemat $(50 \mathrm{~cm}$ of $\mathrm{Hg}$ vacuum). Before fixation, the volume and density of each tissue sample was determined by Archimedes' principle. After paraffin impregnation, the volume of each sample was again determined by Archimedes' principle but absolute alcohol was substituted for water as the displacement fluid.

\section{Semen characteristics}

\section{RESULTS}

The mean values for certain semen characteristics are presented in Table 1. More detailed information on the semen characteristics of the boars has been presented elsewhere (Swierstra \& Rahnefeld, 1967). For each semen component the difference between breeds was not significant. However, boars within breeds differed $(P<0.01)$ with respect to total volumes, strained volumes, gel volumes, spermatozoa concentrations and total spermatozoa per ejaculate. The total number of spermatozoa per ejaculate increased gradually during the first 5 weeks of the collection period and then remained relatively constant (Text-fig. 1). This increase in spermatozoa output was associated with an increase in spermatozoa concentrations and a slight decrease in ejaculate volumes. Only the last ten ejaculates were used to calculate spermatozoa output for comparison with DSP. The spermatozoa output/48 hr was $28.9 \pm 1.1 \times 10^{9}$ for the Yorkshire boars and $29 \cdot 7 \pm 1 \cdot 1 \times 10^{9}$ for the Lacombe boars. These values include a $3.28 \%$ correction for spermatozoa losses in the collection equipment and gelatinous fractions of the ejaculates (Swierstra \& Rahnefeld, 1967).

\section{Testis density and shrinkage due to histological processing}

The mean testis density was 1.041 for Yorkshires and 1.038 for Lacombes. 
TABLE 1

SEMEN GHARACTERISTICS OF YORKSHIRE AND LAGOMBE BOARS EJAGULATED AT 48-HOUR INTERVALS

\begin{tabular}{|c|c|c|c|c|}
\hline \multirow{2}{*}{ Characteristic } & \multicolumn{2}{|c|}{ Yorkshire boars } & \multicolumn{2}{|c|}{ Lacombe boars } \\
\hline & Mean & Range* & Mean & Range* \\
\hline $\begin{array}{l}\text { No. of boars } \\
\text { No. of ejaculates } \\
\text { Age at start of collection (months) } \\
\text { Total volume (ml) } \\
\text { Strained volume }(\mathrm{ml}) \\
\text { Gel volume }(\mathrm{ml}) \\
\text { Sperm concentration }\left(10^{6} / \mathrm{ml}\right) \\
\text { Motile sperm. }(\%) \\
\text { Total sperm./ejaculate }\left(10^{9}\right)\end{array}$ & $\begin{array}{c}10 \\
290 \\
9 \cdot 4 \\
235 \\
186 \\
49 \\
147 \\
74 \\
23 \cdot 8\end{array}$ & $\begin{array}{c}8 \cdot 6 \text { to } 9 \cdot 8 \\
150 \text { to } 299 \\
118 \text { to } 254 \\
31 \text { to } 73 \\
78 \text { to } 219 \\
68 \text { to } 80 \\
20 \cdot 7 \text { to } 28 \cdot 3\end{array}$ & $\begin{array}{c}10 \\
290 \\
9 \cdot 4 \\
244 \\
192 \\
51 \\
123 \\
62 \\
22 \cdot 3\end{array}$ & $\begin{array}{r}8.4 \text { to } 9.8 \\
166 \text { to } 339 \\
125 \text { to } 282 \\
41 \text { to } 71 \\
68 \text { to } 178 \\
43 \text { to } 72 \\
18.8 \text { to } 33.7\end{array}$ \\
\hline
\end{tabular}

* Figures are on a per boar basis (av. for twenty-nine ejaculates/boar).

$\dagger$ Corrected for spermatozoa losses in collection equipment and gel.

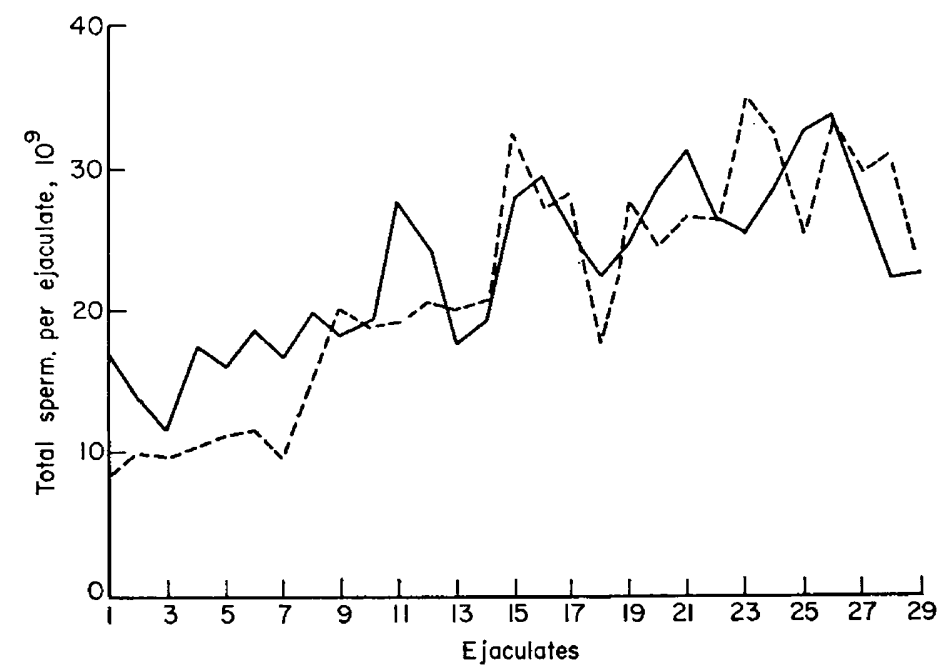

Text-Fig. 1. Mean spermatozoa output for ten Yorkshire boars $(-\longrightarrow)$ and ten Lacombe boars (--- ), ejaculated at 48-hr intervals for an 8-week period.

Differences in testis density between breeds and between right and left testes were not significant. However, among animals within breeds testis density differed $(P<0.01)$.

Shrinkage of testis tissue was affected by the duration of fixation and paraffin impregnation (Table 2). Less shrinkage occurred when tissue was fixed for 9 days rather than for 3 or 6 days. Leaving testis tissue in paraffin for a total of $180 \mathrm{~min}$ rather than $90 \mathrm{~min}$ resulted in more shrinkage $(P<0.01)$. Although the extent of shrinkage did not differ between the two breeds, the differences among animals within breeds were highly significant. 
TABLE 2

SHRINKAGE OF TESTICULAR TISSUE DUE TO DIFFERENT METHODS OF HISTOLOGICAL PROCESSING

\begin{tabular}{l|c|c|c|c|c|c|c}
\hline \multirow{2}{*}{$\begin{array}{c}\text { Method } \\
\text { of } \\
\text { processing }\end{array}$} & $\begin{array}{c}\text { \% o of } \\
\text { original vol. } \dagger \\
\text { (mean } \pm \text { S.E. })\end{array}$ & \multicolumn{6}{|c}{ Sources of variation $\ddagger$} \\
\hline I & $47 \cdot 6 \pm 0.6$ & 24 & $4: B$ & $T$ & $B T$ & $T A: B$ & $O: T A B$ \\
II & $47.7 \pm 0.6$ & 33 & $42 * *$ & $6 *$ & $(0)$ & 8 & 13 \\
III & $46 \cdot 3 \pm 0.6$ & 16 & $44 * *$ & $(0)$ & $(0)$ & $(0)$ & 25 \\
IV & $49 \cdot 2 \pm 0.7$ & 21 & 14 & 1 & $(0)$ & 6 & 34 \\
\hline
\end{tabular}

* $P<0.05 ; * * P<0.01$.

$\dagger \%$ of original volume remaining after fixation, dehydration and paraffin impregnation.

$\ddagger$ Breeds $(\mathrm{B})=2$ (fixed), Animals within breeds $(\mathrm{A}: \mathrm{B})=5$ (random), Testes $(T)=2$ (fixed), Observations $(O)=2$ (random). Figures are percentages of total variance. Negative variance components are denoted by $(0)$ and are not included in the computation of the percentages.

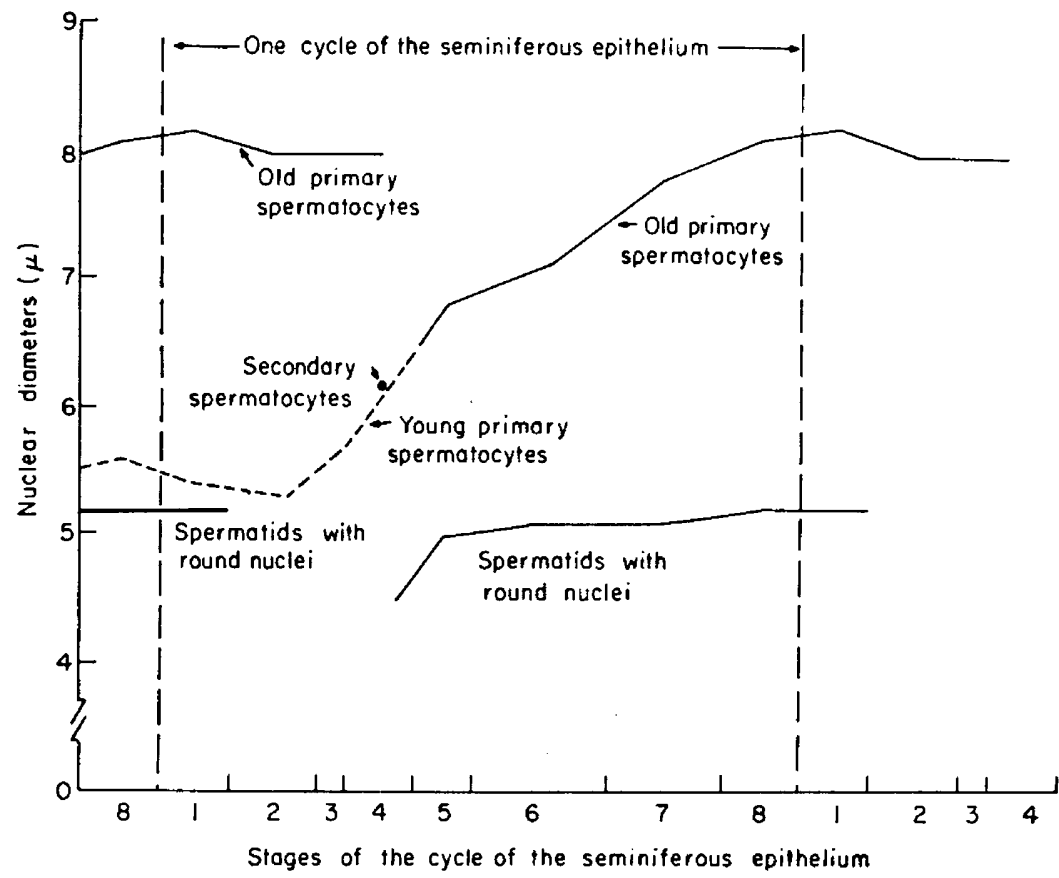

TEXT-FIG. 2. Nuclear diameters of certain porcine germ cells during the eight stages of the cycle of the seminiferous epithelium. Sixty nuclei of each cell type were measured per stage.

A schedule of 3 days fixation and $90 \mathrm{~min}$ of paraffin impregnation (three changes of $30 \mathrm{~min}$ each) was adopted for processing the testis tissue from the boars used for studying DSP. Thus, the value 0.476 was used in all computations to correct for shrinkage due to histological processing.

\section{Testis composition and staining techniques}

The testes of the Yorkshires and Lacombes contained 2.38 $\pm 0 \cdot 15$ and 2.31 \pm 
$0.12 \%$ of round spermatid nuclei, respectively. This difference and differences among animals within breeds (Tables 3 and 4 ) were not significant. The respective values for the percentage of round spermatid nuclei in right and left testes were $2 \cdot 33 \pm 0 \cdot 04$ and $2 \cdot 36 \pm 0 \cdot 03$, and in locations A, B and C $2 \cdot 32 \pm$ $0 \cdot 06,2 \cdot 41 \pm 0 \cdot 05$ and $2 \cdot 30 \pm 0 \cdot 05$. Differences between right and left testes and among the three locations were not significant.

TABLE 3

SPERMATOZOA PRODUCTION AND SPERMATOZOA OUTPUT OF YORKSHIRE BOARS

\begin{tabular}{|c|c|c|c|c|c|c|c|c|c|}
\hline \multirow[b]{2}{*}{ Boar } & \multirow[b]{2}{*}{ Testis } & \multirow{2}{*}{$\begin{array}{c}\text { Testis } \\
w t . \\
(g)\end{array}$} & \multirow{2}{*}{$\begin{array}{c}\text { Tunica } \\
\text { albuginea } \\
\text { wt. } \\
\text { (g) }\end{array}$} & \multirow{2}{*}{$\begin{array}{c}\text { Corrected } \\
\text { testis } \\
\text { volume* } \\
(\mathrm{ml})\end{array}$} & \multirow{2}{*}{$\begin{array}{l}\text { Round } \\
\text { spermatid } \\
\text { nuclei in } \\
\text { testis } \\
(\%)\end{array}$} & \multicolumn{2}{|c|}{$D S P$} & \multirow{2}{*}{$\begin{array}{c}\text { Sperm. } \\
\text { output } \\
\text { per } \\
48 \mathrm{hr} \dagger \\
\left(10^{9}\right)\end{array}$} & \multirow[b]{2}{*}{$\begin{array}{c}\text { Sperm. } \\
\text { output } \\
\text { as } \% \\
D S P\end{array}$} \\
\hline & & & & & & $\begin{array}{c}\text { per } \\
\text { testis } \\
\left(10^{9}\right)\end{array}$ & $\begin{array}{c}\text { per } \\
\text { boar } \\
\left(10^{9}\right)\end{array}$ & & \\
\hline 84 & $\begin{array}{l}\mathrm{R} \\
\mathrm{L}\end{array}$ & $\begin{array}{l}348 \cdot 1 \\
407 \cdot 2\end{array}$ & $\begin{array}{l}21 \cdot 2 \\
20.8\end{array}$ & $\begin{array}{l}147 \cdot 9 \\
174.8\end{array}$ & $\begin{array}{l}2 \cdot 32 \\
2 \cdot 22\end{array}$ & $\begin{array}{l}8 \cdot 0 \\
9 \cdot 0\end{array}$ & $17 \cdot 0$ & $36 \cdot 7$ & 108 \\
\hline 173 & $\begin{array}{l}\mathrm{R} \\
\mathrm{L}\end{array}$ & $\begin{array}{l}360 \cdot 4 \\
388 \cdot 5\end{array}$ & $\begin{array}{l}19 \cdot 6 \\
20 \cdot 5\end{array}$ & $\begin{array}{l}154 \cdot 2 \\
166 \cdot 5\end{array}$ & $\begin{array}{l}2 \cdot 40 \\
2 \cdot 39\end{array}$ & $\begin{array}{l}8 \cdot 6 \\
9 \cdot 2\end{array}$ & $17 \cdot 8$ & $33 \cdot 1$ & 93 \\
\hline 352 & $\begin{array}{l}\mathrm{R} \\
\mathrm{L}\end{array}$ & $\begin{array}{l}339 \cdot 5 \\
342 \cdot 2\end{array}$ & $\begin{array}{l}24 \cdot 3 \\
22 \cdot 9\end{array}$ & $\begin{array}{l}142 \cdot 6 \\
144 \cdot 4\end{array}$ & $\begin{array}{l}2 \cdot 22 \\
2 \cdot 50\end{array}$ & $\begin{array}{l}7 \cdot 4 \\
8 \cdot 4\end{array}$ & $15 \cdot 8$ & $27 \cdot 0$ & 85 \\
\hline 402 & $\begin{array}{l}\mathrm{R} \\
\mathrm{L}\end{array}$ & $\begin{array}{l}275 \cdot 7 \\
288 \cdot 5\end{array}$ & $\begin{array}{l}15 \cdot 8 \\
15 \cdot 7\end{array}$ & $\begin{array}{l}117.6 \\
123.4\end{array}$ & $\begin{array}{l}2 \cdot 33 \\
2 \cdot 56\end{array}$ & $\begin{array}{l}6 \cdot 4 \\
7 \cdot 3\end{array}$ & $13 \cdot 7$ & $24 \cdot 1$ & 88 \\
\hline 441 & $\begin{array}{l}\mathrm{R} \\
\mathrm{L}\end{array}$ & $\begin{array}{l}342 \cdot 0 \\
359 \cdot 5\end{array}$ & $\begin{array}{l}18 \cdot 8 \\
19 \cdot 2\end{array}$ & $\begin{array}{l}146 \cdot 2 \\
154 \cdot 0\end{array}$ & $\begin{array}{l}2 \cdot 54 \\
2 \cdot 41\end{array}$ & $\begin{array}{l}8 \cdot 6 \\
8 \cdot 6\end{array}$ & $17 \cdot 2$ & $31 \cdot 1$ & 90 \\
\hline 635 & $\begin{array}{l}\mathrm{R} \\
\mathrm{L}\end{array}$ & $\begin{array}{l}300 \cdot 7 \\
311 \cdot 1\end{array}$ & $\begin{array}{l}18 \cdot 8 \\
19 \cdot 1\end{array}$ & $\begin{array}{l}127 \cdot 5 \\
132 \cdot 1\end{array}$ & $\begin{array}{l}2 \cdot 23 \\
2 \cdot 22\end{array}$ & $\begin{array}{l}6 \cdot 6 \\
6 \cdot 8\end{array}$ & 13.4 & $25 \cdot 5$ & 95 \\
\hline 714 & $\begin{array}{l}\mathrm{R} \\
\mathbf{L}\end{array}$ & $\begin{array}{l}313.5 \\
270.5\end{array}$ & $\begin{array}{l}17 \cdot 5 \\
18 \cdot 9\end{array}$ & $\begin{array}{l}133.9 \\
113.8\end{array}$ & $\begin{array}{l}2 \cdot 14 \\
2 \cdot 50\end{array}$ & $\begin{array}{l}6 \cdot 7 \\
6 \cdot 6\end{array}$ & $13 \cdot 3$ & $19 \cdot 0$ & 71 \\
\hline 742 & $\begin{array}{l}\mathbf{R} \\
\mathbf{L}\end{array}$ & $\begin{array}{l}442.5 \\
409 \cdot 0\end{array}$ & $\begin{array}{l}26 \cdot 8 \\
28 \cdot 9\end{array}$ & $\begin{array}{l}188 \cdot 1 \\
171 \cdot 9\end{array}$ & $\begin{array}{l}2 \cdot 08 \\
2 \cdot 24\end{array}$ & $\begin{array}{l}9 \cdot 1 \\
9 \cdot 0\end{array}$ & $18 \cdot 1$ & $32 \cdot 9$ & 91 \\
\hline 921 & $\begin{array}{l}\mathbf{R} \\
\mathbf{L}\end{array}$ & $\begin{array}{l}375 \cdot 1 \\
402 \cdot 4\end{array}$ & $\begin{array}{l}19 \cdot 4 \\
23 \cdot 2\end{array}$ & $\begin{array}{l}160.9 \\
171.6\end{array}$ & $\begin{array}{l}2 \cdot 35 \\
2 \cdot 68\end{array}$ & $\begin{array}{r}8 \cdot 8 \\
10 \cdot 7\end{array}$ & $19 \cdot 5$ & $29 \cdot 8$ & 76 \\
\hline 941 & $\begin{array}{l}\mathbf{R} \\
\mathbf{L}\end{array}$ & $\begin{array}{l}343 \cdot 1 \\
362 \cdot 0\end{array}$ & $\begin{array}{l}19 \cdot 5 \\
20 \cdot 9\end{array}$ & $\begin{array}{l}146 \cdot 4 \\
154 \cdot 3\end{array}$ & $\begin{array}{l}2 \cdot 69 \\
2 \cdot 67\end{array}$ & $\begin{array}{l}9 \cdot 2 \\
9 \cdot 6\end{array}$ & $18 \cdot 8$ & $30 \cdot 1$ & 80 \\
\hline Mean & & $349 \cdot 1$ & $20 \cdot 6$ & $148 \cdot 6$ & $2 \cdot 38$ & 8.2 & $16 \cdot 5$ & 28.9 & 88 \\
\hline
\end{tabular}

* Values obtained by the formula given in Materials and Methods section.

$\dagger$ Based on the number of spermatozoa in the last ten ejaculates, and corrected for losses in the collection equipment and in the gelatinous fraction of the ejaculate.

The analysis of variance indicated that there was no significant difference between the techniques of the technicians. The percentage of round spermatid nuclei in Feulgen-stained sections was $2.31 \pm 0.04$ and in PAS-haem-stained sections $2 \cdot 38 \pm 0 \cdot 03(P>0 \cdot 10)$.

Nuclear diameters of spermatids showed little variation from the time spermatids were formed until the elongation of the nuclei (Text-fig. 2).

\section{Testis size, spermatozoa production and spermatozoa output}

The mean testis weight of the Yorkshire boars was $349 \cdot 1 \mathrm{~g}$ and that of the Lacombe boars $389.1 \mathrm{~g}$ (Tables 3 and 4 ). This difference between breeds was not significant. However, animals within breeds differed with respect to paired 
TABLE 4

SPERMATOZOA PRODUCTION AND SPERMATOZOA OUTPUT OF LAGOMBE BOARS

\begin{tabular}{|c|c|c|c|c|c|c|c|c|c|}
\hline \multirow[b]{2}{*}{ Boar } & \multirow[b]{2}{*}{ Testis } & \multirow{2}{*}{$\begin{array}{c}\text { Testis } \\
\text { wet. } \\
(\mathrm{g})\end{array}$} & \multirow{2}{*}{$\begin{array}{c}\text { Tunica } \\
\text { albuginea } \\
\text { wt. } \\
(g)\end{array}$} & \multirow{2}{*}{$\begin{array}{c}\text { Corrected } \\
\text { testis } \\
\text { volume* } \\
\quad(m l)\end{array}$} & \multirow{2}{*}{$\begin{array}{c}\text { Round } \\
\text { spermatid } \\
\text { nuclei in } \\
\text { testis } \\
(\%)\end{array}$} & \multicolumn{2}{|c|}{$D S P$} & \multirow{2}{*}{$\begin{array}{c}\text { Sperm. } \\
\text { output } \\
\text { per } \\
48 \mathrm{hr} \dagger \\
\left(10^{9}\right)\end{array}$} & \multirow{2}{*}{$\begin{array}{l}\text { Sperm. } \\
\text { output } \\
\text { as } \% \\
D S P\end{array}$} \\
\hline & & & & & & $\begin{array}{c}\text { per } \\
\text { testis } \\
\left(10^{9}\right)\end{array}$ & $\begin{array}{c}\text { per } \\
\text { boar } \\
\left(10^{9}\right)\end{array}$ & & \\
\hline 143 & $\begin{array}{l}\mathrm{R} \\
\mathrm{L}\end{array}$ & $\begin{array}{l}404 \cdot 0 \\
429 \cdot 1\end{array}$ & $\begin{array}{l}31 \cdot 4 \\
33 \cdot 2\end{array}$ & $\begin{array}{l}169 \cdot 0 \\
179.6\end{array}$ & $\begin{array}{l}2 \cdot 20 \\
2 \cdot 14\end{array}$ & $\begin{array}{l}8 \cdot 6 \\
8 \cdot 9\end{array}$ & $17 \cdot 5$ & $29 \cdot 3$ & 84 \\
\hline 382 & $\begin{array}{l}\mathbf{R} \\
\mathbf{L}\end{array}$ & $\begin{array}{l}331.6 \\
350 \cdot 0\end{array}$ & $\begin{array}{l}22 \cdot 8 \\
24 \cdot 2\end{array}$ & $\begin{array}{l}140 \cdot 1 \\
147 \cdot 8\end{array}$ & $\begin{array}{l}2 \cdot 25 \\
2 \cdot 14\end{array}$ & $\begin{array}{l}7 \cdot 3 \\
7 \cdot 4\end{array}$ & $14 \cdot 7$ & $24 \cdot 7$ & 84 \\
\hline 392 & $\begin{array}{l}\mathrm{R} \\
\mathrm{L}\end{array}$ & $\begin{array}{l}544 \cdot 2 \\
466 \cdot 2\end{array}$ & $\begin{array}{l}30 \cdot 2 \\
31 \cdot 0\end{array}$ & $\begin{array}{l}233 \cdot 2 \\
197 \cdot 4\end{array}$ & $\begin{array}{l}2 \cdot 32 \\
2 \cdot 22\end{array}$ & $\begin{array}{l}12 \cdot 6 \\
10 \cdot 2\end{array}$ & $22 \cdot 8$ & $29 \cdot 2$ & 64 \\
\hline 421 & $\begin{array}{l}\mathrm{R} \\
\mathrm{L}\end{array}$ & $\begin{array}{l}304 \cdot 5 \\
320 \cdot 5\end{array}$ & $\begin{array}{l}21 \cdot 3 \\
23 \cdot 7\end{array}$ & $\begin{array}{l}128 \cdot 5 \\
134 \cdot 6\end{array}$ & $\begin{array}{l}2 \cdot 46 \\
2 \cdot 38\end{array}$ & $\begin{array}{l}7 \cdot 3 \\
7 \cdot 5\end{array}$ & $14 \cdot 8$ & $39 \cdot 6$ & 100 \\
\hline 452 & $\begin{array}{l}\mathrm{R} \\
\mathrm{L}\end{array}$ & $\begin{array}{l}420 \cdot 0 \\
470 \cdot 1\end{array}$ & $\begin{array}{l}23 \cdot 9 \\
27 \cdot 0\end{array}$ & $\begin{array}{l}179 \cdot 7 \\
201 \cdot 1\end{array}$ & $\begin{array}{l}2 \cdot 25 \\
2 \cdot 30\end{array}$ & $\begin{array}{r}9 \cdot 4 \\
10 \cdot 8\end{array}$ & $20 \cdot 2$ & $39 \cdot 6$ & 98 \\
\hline 471 & $\begin{array}{l}\mathrm{R} \\
\mathrm{L}\end{array}$ & $\begin{array}{l}391.8 \\
398.8\end{array}$ & $\begin{array}{l}23 \cdot 2 \\
26 \cdot 4\end{array}$ & $\begin{array}{l}167 \cdot 2 \\
169 \cdot 0\end{array}$ & $\begin{array}{l}2 \cdot 14 \\
2 \cdot 13\end{array}$ & $\begin{array}{l}8 \cdot 3 \\
8 \cdot 4\end{array}$ & $16 \cdot 7$ & $32 \cdot 2$ & 96 \\
\hline 591 & $\begin{array}{l}\mathrm{R} \\
\mathrm{L}\end{array}$ & $\begin{array}{l}343.9 \\
347.5\end{array}$ & $\begin{array}{l}19 \cdot 2 \\
19 \cdot 8\end{array}$ & $\begin{array}{l}147 \cdot 3 \\
148 \cdot 7\end{array}$ & $\begin{array}{l}2 \cdot 42 \\
2 \cdot 33\end{array}$ & $\begin{array}{l}8 \cdot 3 \\
8 \cdot 1\end{array}$ & $16 \cdot 4$ & $32 \cdot 7$ & 100 \\
\hline 676 & $\begin{array}{l}\mathrm{R} \\
\mathrm{L}\end{array}$ & $\begin{array}{l}346 \cdot 6 \\
399 \cdot 3\end{array}$ & $\begin{array}{l}22 \cdot 6 \\
24 \cdot 5\end{array}$ & $\begin{array}{l}147 \cdot 0 \\
170 \cdot 1\end{array}$ & $\begin{array}{l}2 \cdot 53 \\
2 \cdot 48\end{array}$ & $\begin{array}{l}8 \cdot 6 \\
9 \cdot 8\end{array}$ & $18 \cdot 4$ & $24 \cdot 3$ & 66 \\
\hline 679 & $\begin{array}{l}\mathrm{R} \\
\mathrm{L}\end{array}$ & $\begin{array}{l}342.5 \\
357.0\end{array}$ & $\begin{array}{l}19 \cdot 0 \\
18 \cdot 9\end{array}$ & $\begin{array}{l}146 \cdot 8 \\
153 \cdot 4\end{array}$ & $\begin{array}{l}2 \cdot 58 \\
2 \cdot 26\end{array}$ & $\begin{array}{l}8 \cdot 8 \\
8 \cdot 1\end{array}$ & $16 \cdot 9$ & $23 \cdot 8$ & 70 \\
\hline 1012 & $\begin{array}{l}\mathrm{R} \\
\mathrm{L}\end{array}$ & $\begin{array}{l}409 \cdot 8 \\
420 \cdot 0\end{array}$ & $\begin{array}{l}20 \cdot 5 \\
18 \cdot 8\end{array}$ & $\begin{array}{l}176 \cdot 6 \\
182 \cdot 1\end{array}$ & $\begin{array}{l}2 \cdot 17 \\
2 \cdot 43\end{array}$ & $\begin{array}{r}8 \cdot 9 \\
10 \cdot 3\end{array}$ & $19 \cdot 2$ & $32 \cdot 0$ & 83 \\
\hline Mean & & 389.9 & $24 \cdot 1$ & 165.9 & $2 \cdot 31$ & 8.9 & $17 \cdot 8$ & $29 \cdot 7$ & 83 \\
\hline
\end{tabular}

* Values obtained by the formula given in the Materials and Methods section.

$\dagger$ Based on the number of spermatozoa in the last ten ejaculates, and corrected for losses in the collection equipment and in the gelatinous fraction of the ejaculate.

TABLE 5

ANALYSIS OF VARIANGE OF PREDIGTED DAILY SPERMATOZOA PRODUGTION

\begin{tabular}{l|c|c|c|c|c}
\hline $\begin{array}{c}\text { Source of } \\
\text { variation* }\end{array}$ & d.f. & $\begin{array}{c}\text { Mean } \\
\text { square }\end{array}$ & Expectation of mean square & $\begin{array}{c}F \\
\text { Ratio }\end{array}$ & $\begin{array}{c}\text { Level of } \\
\text { probability }\end{array}$ \\
\hline $\mathrm{B}$ & 1 & $4 \cdot 23$ & $\sigma_{\mathrm{w}}^{2}+2 \sigma_{\mathrm{a}: \mathrm{b}}^{2}+20 \sigma_{\mathrm{b}}^{2}$ & $1 \cdot 47$ & $P>0 \cdot 10$ \\
$\mathrm{~T}$ & 1 & 1.30 & $\sigma_{\mathrm{w}}^{2}+\sigma_{\mathrm{a}: \mathrm{b}}^{2}+20 \sigma_{\mathrm{t}}^{2}$ & $3 \cdot 10$ & $P>0 \cdot 05$ \\
$\mathrm{BT}$ & 1 & 0.48 & $\sigma_{\mathrm{w}}^{2}+\sigma_{\mathrm{a} t: \mathrm{b}}^{2}+10 \sigma_{\mathrm{bt}}^{2}$ & $1 \cdot 14$ & $P>0.25$ \\
$\mathrm{~A}: \mathrm{B} \dagger$ & 18 & $2 \cdot 87$ & $\sigma_{\mathrm{w}}^{2}+2 \sigma_{\mathrm{a}: \mathrm{b}}^{2}$ & $6 \cdot 83$ & $P<0.01$ \\
$\mathrm{AT}: \mathrm{B}$ & 18 & 0.42 & $\sigma_{\mathrm{w}}^{2}+\sigma_{\mathrm{at}: \mathrm{b}}^{2}$ & & \\
\hline
\end{tabular}

* Breeds (B) $=2$ (fixed); Testes (T) $=2$ (fixed); Animals (A) $=10$ (random); Colon denotes a within classification.

$\dagger \mathbf{F}$ ratio was calculated by using $\mathrm{AT}: \mathrm{B}$ as denominator mean square.

testis weight $(P<0 \cdot 01)$. The tunica albuginea accounted for $6 \cdot 1 \%$ of the testis weight.

The DSP of the Yorkshires was $16.5 \pm 0.7 \times 10^{9}$ and that of the Lacombes $17 \cdot 8 \pm 0 \cdot 8 \times 10^{9}$. Although this difference between the breeds was not significant, DSP differed significantly among boars within breeds (Table 5). 
Paired testes weight was correlated $(r=+0.90, P<0 \cdot 01)$ with DSP. The DSP can be estimated from paired testes weight by the following regression equation in which testes weight is expressed in grams and DSP in thousand millions:

$$
\text { DSP }=2 \cdot 3+0.02 \text { (paired testes weight) }
$$

Based on the last ten ejaculates for each boar, spermatozoa output $/ 48 \mathrm{hr}$ was $28.9 \pm 1 \cdot 1 \times 10^{9}$ for the Yorkshires and $29 \cdot 7 \pm 1 \cdot 1 \times 10^{9}$ for the Lacombes. Spermatozoa output equalled $88 \%$ of the DSP for the Yorkshires and $83 \%$ of the DSP for the Lacombes (Tables 3 and 4). Spermatozoa output was significantly correlated $(r=+0.54, P<0.05)$ with spermatozoa production.

The DSP/g net testis weight (gross testis weight minus the weight of the tunica albuginea) for the Yorkshire and Lacombe boars was 25.1 $\pm 0.4 \times 10^{6}$ and $24 \cdot 3 \pm 0.3 \times 10^{6}$, respectively. This difference between breeds was not significant.

\section{DISGUSSION}

Few reports have been published in which spermatozoa production was compared with spermatozoa output. In the present study the DSP of 11-month-old Yorkshire and Lacombe boars was $16.5 \times 10^{9}$ and $17.8 \times 10^{9}$, respectively. Spermatozoa output was $88 \%$ of the spermatozoa production in the Yorkshire boars and $83 \%$. of the spermatozoa production in the Lacombe boars when semen samples were collected at 48-hr intervals. Kennelly \& Foote (1964) measured DSP and DSO in six 2-year-old Yorkshire boars. The DSO of these boars was $19.7 \times 10^{9}$ and this equalled $63 \%$ of the DSP as measured by quantitative testicular histology. However, these researchers did not consider shrinkage due to histological processing and correction for this would undoubtedly lower the estimate of DSP.

Amann \& Almquist (1962) compared DSO and DSP of twelve dairy bulls. The DSO averaged $4.81 \times 10^{9}$ when these bulls were ejaculated six times per week with intensive sexual preparation. This represented only $42 \%$ of the mean DSP of $11.49 \times 10^{9}$. Losses of spermatozoa in the artificial vagina were not accounted for. Swierstra (1966) measured spermatozoa production and output of seven 18-month-old Shorthorn bulls. The DSP as measured by quantitative testicular histology, was $5.3 \times 10^{9}$ and $25 \%$ of these spermatozoa were ejaculated when semen samples were collected at 48-hr intervals, using electro-stimulation. Thus, in boars a much larger percentage of the spermatozoa produced by the testes are ejaculated as compared to bulls.

In the present study, testis weight and DSP were highly correlated $(r=$ $+0.90, P<0.01)$. One reason for this high correlation is that testis weight is one of the two main variables used when calculating DSP.

The DSP/g gross testis weight averaged $23.1 \times 10^{6}$ for the twenty boars. Values for Shorthorn bulls of $14.8 \times 10^{6}$ (Swierstra, 1966), for dairy bulls of $17.7 \times 10^{6}$ (Amann \& Almquist, 1962) and for rams of $12.2 \times 10^{6}$ (Ortavant, 1959) have been reported. There are many reasons for these differences in DSP/g of testis among species. The duration of the cycle of the seminiferous 
epithelium is 8.6 days for boars (Swierstra, 1968), 13.5 days for bulls (Hochereau, Courot \& Ortavant, 1964) and 10.4 days for rams (Ortavant, 1956). Furthermore, one stem spermatogonium probably produces ninety-six spermatozoa in boars as contrasted to sixty-four spermatozoa in rams and bulls (Ortavant, 1959; Amann, 1962b).

When DSP, as determined by the procedure outlined in this paper, is compared with DSO then it is imperative that the time interval between the two measurements be taken into account. In the boar it takes about 11 days for spermatids with round nuclei to pass into the caput epididymidis as spermatozoa. An additional $10 \cdot 2$ days is needed for these spermatozoa to traverse the epididymis (Swierstra, 1968). Thus, for the boar the two measurements are separated by a 21.5 -day interval. In animals with rapidly growing testes this results in a low estimate for DSO as a percentage of DSP. Theoretically, in normal animals the DSO should not be larger than the DSP. For one boar (No. 84) spermatozoa output exceeded the estimated production. The testes of this boar appeared to be normal. Possibly this aberrant value was caused by sampling errors and does not reflect testicular degeneration.

The relative volume of the testes occupied by spermatids with round nuclei did not differ significantly between testes, among boars within breeds, or between breeds. Similarly, Swierstra (1968) found that for boars there generally was a constancy of the relative frequencies of the stages of the seminiferous epithelium. Thus, since the duration of spermatogenesis is constant within a species, DSP is primarily a function of testis size in normal boars.

The procedure outlined for measuring DSP can be used for species other than the boar. However, the constants in the formulae vary among species and they would have to be determined for each species separately.

\section{ACKNOWLEDGMENT}

The author gratefully acknowledges the technical assistance of H. H. S. Bell.

\section{REFERENCES}

Almeuist, J. O. \& Amann, R. P. (1961) Reproductive capacity of dairy bulls. II. Gonadal and extragonadal sperm reserves as determined by direct counts and depletion trials; dimensions and weight of genitalia. 7. Dairy Sci. 44, 1668.

Amann, R. P. (1962a) Reproductive capacity of dairy bulls. III. The effect of ejaculation frequency, unilateral vasectomy, and age on spermatogenesis. Am. F. Anat. 110, 49.

Amann, R. P. (1962b) Reproductive capacity of dairy bulls. IV. Spermatogenesis and testicular germ cell degeneration. Am. F. Anat. 110, 69.

Amann, R. P. \& Almquist, J. O. (1962) Reproductive capacity of dairy bulls. VIII. Direct and indirect measurement of testicular sperm production. F. Dairy Sci. 45, 774.

Chalkley, H. W. (1943) Method for the quantitative morphologic analysis of tissues. 7. natn. Cancer Inst. 4, 47.

GrAy, P. (1958) Handbook of basic microtechnique, 2nd edn, p. 74. McGraw-Hill, New York.

Hale, E. B. \& Almquist, J. O. (1960) Relation of sexual behavior to germ cell output in farm animals. F. Dairy Sci. 43 (Suppl.), 145.

Hochereau, M. T., Courot, M. \& Ortavant, R. (1964) Durée de la spermatogenèse chez le taureau étude par autoradiographie testiculaire. Proc. Vth int. Congr. Anim. Reprod., Trento, Vol III, p. 541.

KenNeliy, J. J. \& Foote, R. H. (1964) Sampling boar testes to study spermatogenesis quantitatively and to predict sperm production. F. Anim. Sci. 23, 160. 
Ortavant, R. (1956) Autoradiographie des cellules germinales du testicule de bélier. Durée des phénomènes spermatogénétiques. Archs Anat. microsc. Morph. exp. 45, 1 .

Ortavant, R. (1959) Spermatogenesis and morphology of the spermatozoon. In: Reproduction in Domestic Animals, Vol. 2, p. 1. Eds. H. H. Cole and P. T. Cupps. Academic Press, New York.

SNedecor, G. W. (1957) Statistical methods, 5th edn. Iowa State University Press, Ames, Iowa.

SWIERSTRA, E. E. (1966) Structural composition of Shorthorn bull testes and daily spermatozoa production as determined by quantitative testicular histology. Can. F. Anim. Sci. 46, 107.

Swierstra, E. E. (1968) Cytology and duration of the cycle of the seminiferous epithelium of the boar; duration of spermatozoan transit through the epididymis. Anat. Rec. 161, (2).

Swierstra, E. E. \& Rahnefeld, G. W. (1967) Semen and testis characteristics in young Yorkshire and Lacombe boars. 7. Anim. Sci. 26, 149.

Young, D. C., Foote, R. H., Turkheimer, A. R. \& Hafs, H. D. (1960) A photoelectric method for estimating the concentration of sperm in boar semen. F. Anim. Sci. 19, 20. 